\title{
Zoroastrian Temple Of Fire Of The South Aral Sea Region Or Temple Of Fire Zhambas Kala
}

\author{
Khakimniyazov Jolmurza Khozhabekovich \\ Candidate Of Historical Sciences, Associate Professor,Karakalpak State University Named \\ After Berdakh, Uzbekistan
}

Journal Website:

http://usajournalshub.c

om/index,php/tajssei

Copyright: Original

content from this work

may be used under the

terms of the creative

commons attributes

4.0 licence.

\section{ABSTRACT}

The article noted the results of the archaeological research of the fortress Zhanbas, including Zoroastrian fire temples and their functional features.

\section{KEYWORDS}

Zoroastrianism, temple of fire or Atesh gah, Altar, priests, Delta of the Akcha River, The Oaks river.

\section{INTRODUCTION}

In the first millennium BC, the nomadic peoples of the Southern Aral Sea region began to settle in the vicinity of this territory, which led to the expansion of settlements and the development of agriculture and irrigation (1.89-93). Archaeological excavations show that the appearance of the first cities in the Khorezm oasis dates back to the 7th-6th centuries BC (2. 82-83., 3. 58-60). This process became especially active in the 5th-3rd centuries. BC.

On the territory of the southern Aral Sea region, religious, scientific and spiritual cultural centers of peoples begin to appear (temples of Kalaly kyr, Guzeli kyr, Aybuyir kala, Akshakhan kala temple, Zhanbas kala fire house, scientific and religious center Koy kyrylgan kala, palace and temples Topirak kala, dakhma Shylpyk and etc.).

In the central part of the city, Zoroastrian fire temples of various architectural styles began to be erected, consisting of pakhsa (adobe) and large-sized mud bricks.

Zhanbas kala is located along the Akchadarya delta (60 km east of Tortkul, IV-III centuries $B C)$. Zhanbas kala was a military city on the 
eastern border of the Khorezm state, it served as a military-strategic, economic, cultural and religious center. Its perfect architectural and military style confirms the high level of development of the economy, politics, culture and plays a huge role in the development of agriculture on the banks of the Oaks River, located on the border of agricultural settlements and a nomadic desert.

The inhabitants of the city were engaged in agriculture (4.74-75). For example, mills and bakeries were discovered in the city. The city has a powerful defensive wall with a total area of 3 hectares and consists of walls with right angles facing the four cardinal points.

Numerous fragments of ceramics, terracotta figurines, various metal products, bracelets, rings, as well as glass beads of various colors and shapes were found in the city. According to archaeologist S.P. Tolstov, who conducted research of the monument, such beads date back to the III-II centuries BC. In the III-II centuries, it is often found in the monuments of the Black Sea region (1.116-117).

The central street (about 30 meters long), starting from the entrance gate, divided the city into two parts. On the opposite side of the gate, at the wall at the end of the street, the fire temple of the Zoroastrians (Atəşgah, Atash-kede, alau-khan) was investigated as a communal sanctuary of fire - a room where the inextinguishable fire of Janbas kala burned on an oval dais, apparently on a metal altar ... (1.95-98, 5.113). The temple complex consists of 4 rooms of different sizes and has an area of $40-25 \mathrm{~m}$. It is located higher than other buildings around it.

The main center of the complex was the main room \# 1. The volume of the room was $4 \times 7.25$ $\mathrm{m}$; a thick layer of ash was found on the floor. Three stages of the cultural layer of the room were studied.

At the first stage, a fire was constantly burning at a height of $12 \mathrm{sm}$ above the floor of an iron altar. Along the north-western and south-western walls of the room there is a low sufa 8-9 sm high from the floor, completely covering the distance to the altar.

At the second stage, where an eternal flame burned, the altar and a low sufa were stretched with lime in equal measure. Along the southeastern wall, curving towards the northeastern and southwestern, there was a narrow brick bench about $40 \mathrm{~cm}$ in height, the upper edge of which was given characteristic wavy outlines by a special selection of brick sizes and figured plastering, probably in order to separate one seat from another ...

At the last stage, the floors of the room were evenly rubbed with lime, and thus the altar was lowered a little lower. (1.95-98).

Such changes in the internal structure of the room can be associated with Zoroastrian religious traditions. According to Zoroastrian traditions, the ashes of the sacred fire, invisible, should not have been thrown out of the room. Therefore, when there was too much of it, it was compacted, covered with clay on top. The ash from the temple could not be thrown into the street and was not drained into the running water. Thus, as a result of the ashes of the sacred fire being poured into the temple itself, the altar was high in the first stage and below the floor in the third stage. (6.61-63).

In general, this ancient layout is extremely close to the layout of the proposed temple of fire in the courtyard of Teshik-kala and just as 
close to the almost identical layout of the Sassanid temple of fire in Shapur-1. (1.97)

Unfortunately, there is no written evidence about the architecture, interior and exterior of Zoroastrian temples. However, in the 1st century $\mathrm{BC}$, according to Strabo, fire temples consisted of cozy rooms with an altar in the middle of a fire room, and magicians (believers, priests) made sure that the sacred fire never extinguished (7-38-39).

There are different scientific opinions among scientists regarding the function of the fire temple in Zhanbas kala. For example, S.P. Tolstov pays special attention to the fourth room of the fire temple complex $(14 \times 8 \mathrm{~m})$. The floor was leveled; fragments of household pottery and animal bones (food waste) were found on it. Such special buildings (men's houses, teahouses) of the Islamic period were built at the mosque, where men gathered and discussed public issues (1.98). In support of this point of view, it was suggested that the fire temple in Zhanbas kala was the "House of Youth" (MF Shabaev), as well as "atashkada" (Atar) or "men's house", the "youth house" was an elementary school among residents of the settlement of Kelteminara (8.2-5).

According to the old Zoroastrian tradition, every believer voluntarily came to the temple of fire (9.24). Zarathushtra rebelled against bloody sacrifices and the desecration of fire with sacrificial blood. They did not sacrifice the living (people, animals, etc.). On the contrary, they sacrificed completely drying out individual fruit trees, which impart a pleasant aroma (fragrant) to the fire temple. The firewood in the altar bowl was of valuable solid wood, including sandalwood; when they burned, the room was filled with a pleasant smell. It is understood that a tree that has not dried up emits smoke an unpleasant odor (smells bad), and this was considered by the Zoroastrians to be the product of the spirit of evil and caused Ahriman (dark power). (9.24). When Ahriman fell upon the material world, he inflicted terrible damage on the sky, water, earth and fire. Having attacked the fire, he defiled it with smoke.

According to scientific observations, the fire temples atashkada and the construction of the altars were different. Some of the altars are permanently located in the same place as the monumental ones, while others are in special vessels and are taken out only when necessary, during special events and ceremonies (14.10-25). The rulers who ruled the country had their own altar (9.23-24), and on the days of reception, the fire was taken out of the temple in special vessels (on the paintings on the walls of houses in the vicinity of Padjikent, the altar had the shape of a cone, resembling a bronze bowl).

A. Mandelstama compares his study of altars with the example of India and makes the following conclusions (11.126). First, the garhapatia (fire of the owner of the house) was a "house fire" or round altar of the hearth, which was genetically related to the work of women keeping the fire in the hearth in the house.

Secondly, ahavania is a sacred fire for sacrificial rites. It was a straight quadrangle (for the priests) associated with the ministry of the people as a community owned by the clergy.

Thirdly, the dakshina fire protects against dangers and evil forces. Its altar was in the shape of a semicircle. 
A. Mandelstam notes that models of round altar burials near the Ertatulhar monument are found in female burials, and rectangular altars in male burials. T. Shirinov, complementing the above facts with his observations, comes to the conclusion that the ateshkads found in the courtyard of the temple in Jarkurtan, square in plan, were priestly; those that were inside the room were male, while the semicircular depression inside the circular one was an altar-amulet, and the outer circle was associated with the female principle (12, p. 76, 77).

Thus, as noted earlier, the city of Zhanbas kala served as a fortress on the border of the eastern part of the Khorezm state ("Tsarist period"), like a dakshina fire burning on the altar in the fire temple complex to protect against the dangers of evil forces. And the magical fourth room of the fire temple complex may have been a fortress for the ruler, priests and tribal elders to consult after fire worship and conduct religious ceremonies as part of the congregation (6.61-63).

In the territories where the Zoroastrian people lived, the functional task of the altar in the ateshkad in the temple complex, regardless of its architectural appearance, is obvious, the eternal fire burning in the ateshkad inside the temple was associated not only with the social life of a person, but also with his spiritual life. with the secrets of his soul. This is a cult place where believers receive spiritual strength and purification by fire.

\section{LIST OF USED LITERATURE}

1. Tolstov S.P. Ancient Khorezm. The experience of historical and archaeological research. Moscow State
University Publishing House. Moscow, 1948.

2. Mambetullaev M. Aral Sea region at the crossroads of Cultures. Samarkand, MITSAI., 2013.

3. Khozhaniyazov G. Fortification of ancient Khorezm (VI century BC IV AD) Tashkent 2007

4. Gulyamov Ya.G. Irrigation history of Khorezm from ancient times to the present day. Tashkent 1957

5. Tolstov S.P. In the footsteps of the ancient Khorezm civilizations. M. 1948

6. Kakimniyazov Zh.Kh. Altars in a Zoroastrian temple of fire. KSU. Bulletin, 2017 № 4.

7. Boyes $M$. Zoroastrians. Beliefs and customs. M., 1987.

8. Aleuov O. Kelteminar school in ancient Khorezm. Materials of the republican scientific and methodological conference. (November 6 - 7, 2007) Nukus. 2007 year

9. Doroshenko E. A. Zoroastrians in Iran. M., 1982.

10. Azimov IM Architecture on the money of the countries of Central Asia // Numismatics of Central Asia. Issue II. Tashkent, 1997.

11. Mandelstam AM Monuments of the Bronze Age in southern Tajikistan // MIA. 1968, No. 145.

12. Shirinov T. Fire altars from the temple of Jarkutan - a monument of the developed Bronze Age in the south of Uzbekistan // IMKU. Issue 23. Tashkent, 1990. 